\title{
In Vivo Antitumor Activity of a Novel Acetazolamide-Cryptophycin Conjugate for the Treatment of Renal Cell Carcinomas
}

\author{
Samuele Cazzamalli, ${ }^{\dagger, \perp}$ Eduard Figueras, ${ }^{\ddagger}, \perp$ Lilla Petho, ${ }^{\ddagger, \S}$ Adina Borbély, ${ }^{\ddagger}$ Christian Steinkühler," \\ Dario Neri, ${ }^{*} \dagger$ and Norbert Sewald $* *$ *0 \\ ${ }^{\dagger}$ Department of Chemistry and Applied Biosciences, Swiss Federal Institute of Technology (ETH Zürich), Vladimir-Prelog-Weg 4, \\ CH-8093 Zürich, Switzerland \\ ${ }^{\ddagger}$ Department of Chemistry, Organic and Bioorganic Chemistry, Bielefeld University, Universitätsstraße 25, D-33615 Bielefeld, \\ Germany \\ ${ }^{\S}$ MTA-ELTE Research Group of Peptide Chemistry, Hungarian Academy of Sciences, Eötvös L. University, H-1117 Budapest, \\ Hungary \\ "Exiris s.r.l., Via Savona 6, I-00182 Rome, Italy
}

Supporting Information

ABSTRACT: Traditional chemotherapeutics used in cancer therapy do not preferentially accumulate in tumor tissues. The conjugation to delivery vehicles like antibodies or small molecules has been proposed as a strategy to increase the tumor uptake and improve the therapeutic window of these drugs. Here, we report the synthesis and the biological evaluation of a novel small molecule-drug conjugate (SMDC) comprising a high-affinity bidentate acetazolamide derivative, targeting carbonic anhydrase IX (CAIX), and cryptophycin, a potent microtubule destabilizer. The biological activity of the novel SMDC was evaluated in vitro, measuring binding to the CAIX antigen by surface plasmon resonance and cytotoxicity against SKRC-52 cells. In vivo studies showed a delayed growth of tumors in nude mice bearing SKRC-52 renal cell carcinomas.

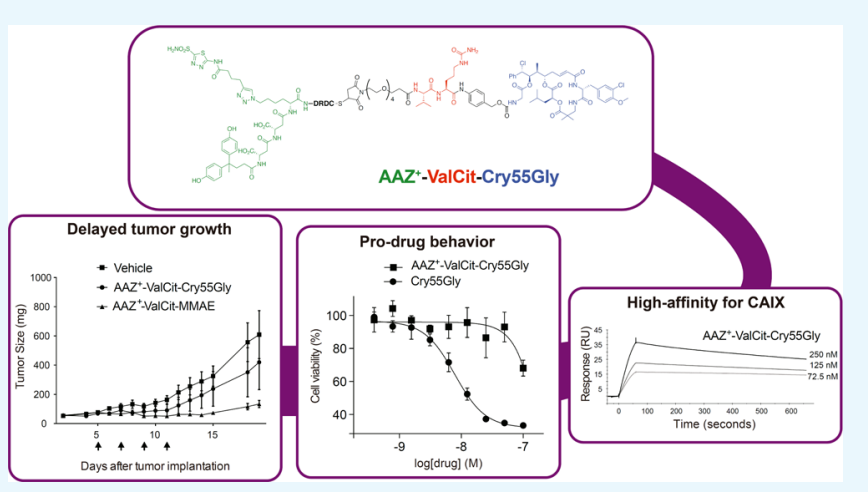

\section{INTRODUCTION}

Most cytotoxic compounds, which are used for cancer chemotherapy, do not accumulate selectively at the site of the disease. ${ }^{1,2}$ The suboptimal biodistribution properties of these drugs limit clinical efficacy and may cause severe side effects. ${ }^{3}$ Antibodies and small molecules that are able to bind accessible tumor-associated antigens have been proposed as carriers to deliver cytotoxic payloads to the tumor site. The corresponding products are called antibody-drug conjugates (ADCs) and small molecule-drug conjugates (SMDCs), respectively. ${ }^{4}$ Four ADCs (Kadcyla, Adcetris, Besponsa, and Mylotarg) have been approved for cancer treatment. ${ }^{5}$

The prolonged circulatory half-life of $\mathrm{ADC}$ products can induce side effects as a result of premature release of the payload. In addition, challenges related to the preparation of ADCs with homogenous drug-antibody ratio, as well as high manufacturing cost, may hinder ADC development. ${ }^{6}$ SMDC products may represent an alternative to ADCs. ${ }^{7}$ Their small size facilitates rapid and uniform diffusion into tissues, ${ }^{8}$ potentially reaching high tumor/organ ratios at earlier time points. Lower cost-of-goods, ${ }^{9}$ lack of immunogenicity, ${ }^{10}$ amenability to chemical synthesis, and easier analytical characterization may represent opportunities for SMDC development compared to ADCs. Promising results from nuclear medicine studies and preclinical experiments have been obtained with certain ligands of folate receptors, ${ }^{11}$ prostatespecific membrane antigen, ${ }^{12}$ somatostatin receptors, ${ }^{13}$ and carbonic anhydrase IX (CAIX), ${ }^{3,7,14}$ indicating that it is possible to target different types of tumors with small organic compounds.

Carbonic anhydrase IX (CAIX) is a transmembrane protein virtually absent in most of the healthy human tissues, with the exception of certain gastrointestinal structures. ${ }^{15,16}$ CAIX represents an ideal target for SMDC development since its expression is enhanced in tumor hypoxia and certain cancer types. A growing body of evidence indicates that binding of antibodies or small ligands to CAIX does not induce receptor internalization. ${ }^{3,17-22}$ We have recently reported the discovery of a noninternalizing acetazolamide derivative from a DNAencoded library and its use as a delivery vehicle for tumor targeting. ${ }^{7,23}$ An SMDC product based on this ligand, called $\mathrm{AAZ}^{+}$, showed a comparable in vivo activity to an $\mathrm{ADC}$

Received: September 11, 2018

Accepted: October 25, 2018

Published: November 2, 2018 


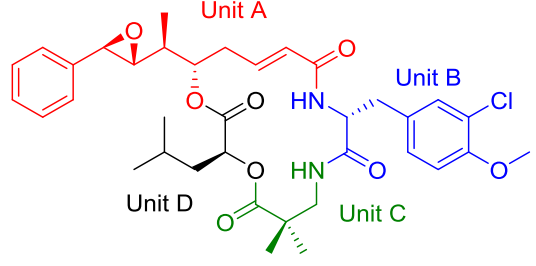

Cryptophycin-52 (1)

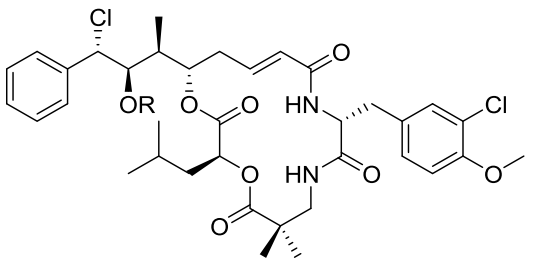

$\mathrm{R}=\mathrm{H}$, Cryptophycin-55 (2)

$\mathrm{R}=\mathrm{COCH}_{2} \mathrm{NH}_{2}$, Cryptophycin-55 glycinate (3)

Figure 1. Structures of cryptophycin-52 (1), cryptophycin-55 (2), and cryptophycin-55 glycinate (3).

Scheme 1. Synthesis of an Acetazolamide-Cryptophycin Conjugate ${ }^{a}$

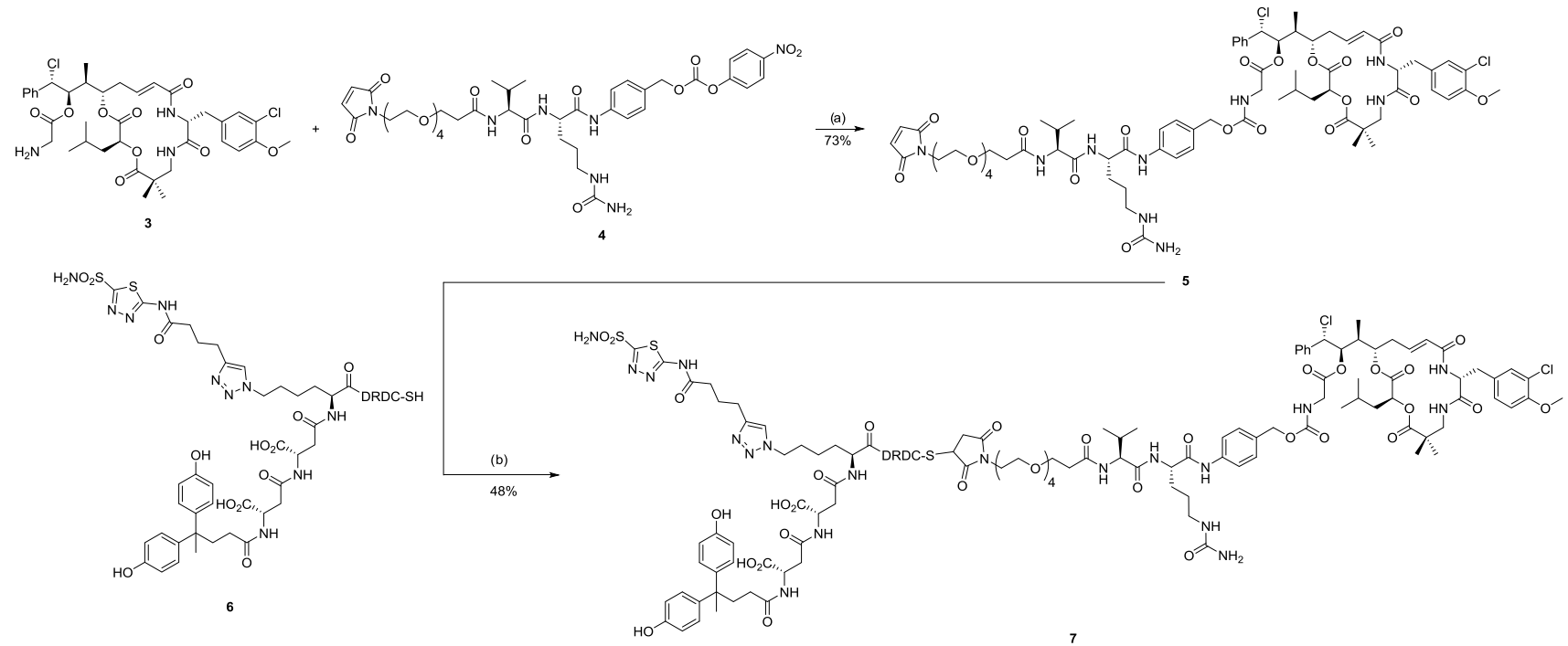

${ }^{a}$ Reagents and conditions: (a) N,N-diisopropylethylamine (DIPEA), dimethylformamide (DMF), room temperature (RT), 3 h; (b) Tris buffered saline (TBS), DMF, RT, o.n.

targeting the same antigen. ${ }^{7}$ Moreover, we could show that the anticancer activity of the SMDC can be enhanced by the combination of immune-oncology drugs like antibodycytokine fusion proteins. ${ }^{14}$

Not only the ligands but also the linker-payload combination is significant for the development of efficacious targeted cytotoxic products. ${ }^{24,25}$ In fact, the failure of early $\mathrm{ADCs}$ and SMDCs was partially due to the insufficient potency of the chosen payloads. The importance of using more potent cytotoxic agents has been recognized, prompting research in the identification of highly active drugs. Indeed, since the tumor-targeting performance of $\mathrm{AAZ}$ and $\mathrm{AAZ}^{+}$decreases at doses above $250 \mathrm{nmol} / \mathrm{kg}$, our groups have searched for cytotoxic payloads, which could potentially outperform conventional drugs used in ADC and SMDC research.

Cryptophycins (Figure 1) are cyclic depsipeptides with a bacterial origin, which show promise as payloads to be used in targeted therapy. ${ }^{26}$ Cryptophycins display a very high cytotoxicity (typically in the low picomolar range) on a broad variety of cancer cells, including multidrug-resistant ones. $^{27}$ Initial studies focused on the total synthesis and application of cryptophycins as traditional chemotherapeutics, but disappointing results in monotherapy phase II clinical trials prompted a focus shift toward ligand-based pharmacodelivery approaches. $^{28,29}$ However, the parental compound lacks an addressable functional group for the conjugation to a homing device. Therefore, research has been focused on the generation of cryptophycin derivatives that can be conjugated and subsequently released, preserving the potent cytotoxicity of the parent compound. ${ }^{30-33}$

The para position of the aromatic ring of unit $A$ has proven to be a suitable position to be modified, and ADCs using this anchoring point have been produced. ${ }^{34-37}$ Another position that can be modified is the epoxide of unit A. Although this site plays an essential role for the high cytotoxicity, it tolerates certain modifications. Cytotoxicity is retained upon epoxide opening with $\mathrm{HCl}$ to give a chlorohydrin, presumably due to the epoxide-forming reverse reaction under physiological conditions. Hence, the secondary alcohol of the chlorohydrin permits conjugation to the homing device, since esterification is an elegant way to stabilize the compound while retaining the cytotoxicity. $^{38}$

\section{RESULTS AND DISCUSSION}

The use of cryptophycin payloads has been studied for the preparation of ADCs, but in vivo applications of cryptophycin-SMDC have not yet been reported. For this reason, we embarked on a project aiming at the synthesis and biological evaluation of a conjugate bearing a bidentate acetazolamide ligand, cleavable Val-Cit dipeptide with para-aminobenzyl selfimmolative part, and cryptophycin-55 glycinate as a payload, and studied its biological effect. Cryptophycin-55 glycinate (3) was prepared as previously described with slight modifications. ${ }^{38}$ The cleavable linker 4 was prepared starting from Fmoc-Val-Cit-PAB; the Fmoc group was removed and a triethylene glycol spacer containing a maleimide moiety was 
coupled to increase the solubility of the conjugate and allow the conjugation to the acetazolamide moiety via Michael addition. Then, the alcohol of the para-aminobenzyl moiety was activated with bis(4-nitrophenyl) carbonate and the linker 4 was obtained in good yield and purity. Next, linker $\mathbf{4}$ was coupled to cryptophycin-55 glycinate (3) via carbamate linkage obtaining 5 with satisfactory yield $(73 \%)$ and purity (Scheme 1). Conjugation of 5 to the acetazolamide ligand $\mathbf{6}$ yielded the final conjugate 7 (48\%) in excellent purity.

The affinity of the novel SMDC (7) to recombinant human CAIX was determined using surface plasmon resonance (SPR) (Figure 2). Conjugate 7 was bound in a concentration-

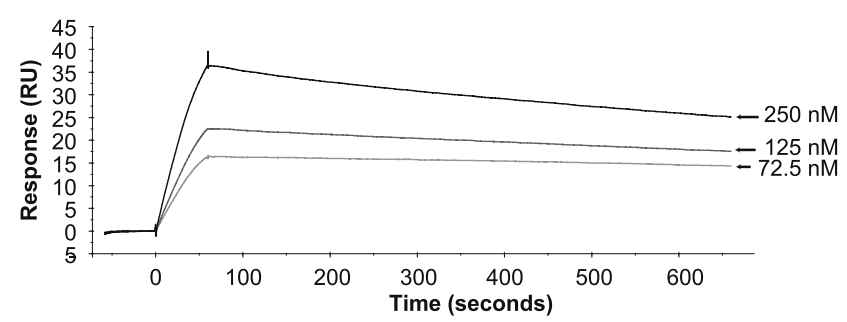

Figure 2. SPR analysis: binding of acetazolamide-cryptophycin conjugate 5 to immobilized CAIX.

dependent manner to immobilized CAIX in agreement with previous data obtained using similar derivatives of $\mathrm{AAZ}^{+}$(i.e., we could calculate an apparent binding constant of $3.4 \mathrm{nM}$ for $\mathrm{AAZ}^{+}$-ValCit-Cry55gly, similar to the $K_{\mathrm{D}}$ value previously reported for $\mathrm{AAZ}^{+}-$ValCit-MMAE).,14

An in vitro cytotoxicity cell-based assay was performed using the cell line SKRC-52 (Figure 3). The unmodified payload 3

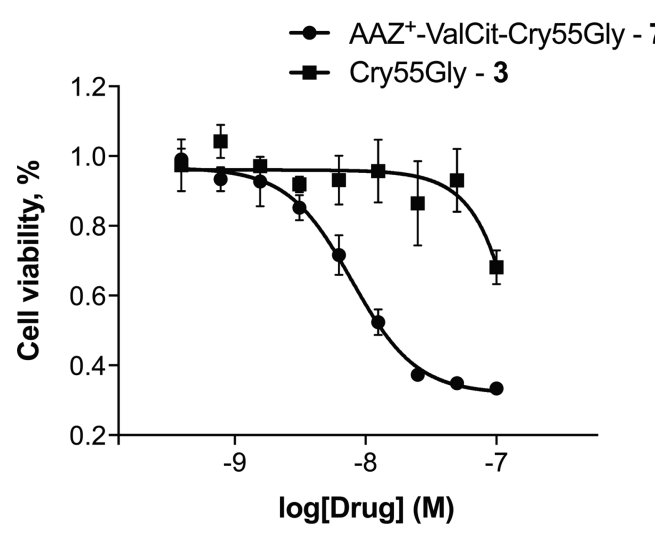

Figure 3. In vitro toxicity of cryptophycin-55 glycinate (unconjugated drug) and compound 7 on the SKRC-52 tumor cells.

showed a cytotoxicity in the low nanomolar range $\left(\mathrm{IC}_{50}=7.9\right.$ $\mathrm{nM}$ ). Indeed, cryptophycin-55 glycinate was remarkably less potent than expected when compared to other cell lines. ${ }^{39}$ Monomethyl auristatin E (MMAE) using the same cell line and protocol showed a $\mathrm{IC}_{50}$ of $1.5 \mathrm{nM}^{24}$ As expected, conjugate 7 showed a decreased cytotoxicity compared to the unmodified drug, proving the prodrug behavior characteristic of noninternalizing conjugates.

The antitumor activity of compound 7 was investigated in vivo in nude mice bearing subcutaneous SKRC-52 renal cell carcinomas (Figure 4). An optimal and safe dose corresponding to $250 \mathrm{nmol} / \mathrm{kg}$ was determined on the basis of doseescalation studies in nude mice (Supporting Information
Figure S5) and previously published biodistribution studies. ${ }^{24}$ Mice treated with compound 7 enjoyed a therapeutic benefit with a slower tumor growth, especially during the treatment $(p$ $=0.05$ at day 14), compared with the control group (saline). In comparison to the lead compound featuring MMAE as the payload administered at the same dose, the therapeutic activity was significantly inferior. Under these experimental conditions, neither acute toxicity nor significant loss of weight could be observed for mice treated with the compounds bearing either cryptophycin or MMAE as the payload.

\section{CONCLUSIONS}

In summary, we have generated a novel cryptophycinacetazolamide conjugate targeting CAIX. The SMDC product showed excellent affinity to the target and a noninternalizing behavior in an in vitro cytotoxicity assay. The compound exhibited a moderate antitumor effect in vivo, which was, however, inferior to that of an analogous compound based on MMAE as the payload. The lower therapeutic activity observed with the cryptophycin-55 glycinate, compared to that of the MMAE conjugate, correlates with the lower in vitro potency of the corresponding free drugs and provides a motivation to search for more potent cryptophycin derivatives.

\section{EXPERIMENTAL SECTION}

4.1. General. The general information about the used materials and methods, NMR, and high-performance liquid chromatography (HPLC) spectra can be found in the Supporting Information.

4.2. Syntheses. 4.2.1. Cryptophycin-55 Glycinate (3). Cryptophycin-55 was prepared as previously reported. ${ }^{32}$ Slightly modified protocol from Liang et al. was used to synthesize cryptophycin-55 glycinate. ${ }^{38}$ Cryptophycin-55 (62 $\mathrm{mg}, 88 \mu \mathrm{mol}, 1$ equiv), DCC (27.2 mg, $132 \mu \mathrm{mol}, 1.5$ equiv $)$, Boc-glycine $(23.1 \mathrm{mg}, 132 \mu \mathrm{mol}, 1.5$ equiv), and 4-DMAP (1.07 mg, $8.8 \mu \mathrm{mol}, 0.1$ equiv) were placed under argon atmosphere and dissolved in $1 \mathrm{~mL}$ of dry dichloromethane (DCM). The solution was stirred for $2 \mathrm{~h} 30 \mathrm{~min}$ at RT. Then, $2 \mathrm{~mL}$ of EtOAc/PE 3:1 was added and the solution was stirred for $10 \mathrm{~min}$. The solution was filtered through Celite, washed with EtOAc/PE 3:1 (100 mL), and the solvent was removed under reduced pressure. The crude was dissolved in $4 \mathrm{~mL}$ of dry DCM, $120 \mu \mathrm{L}$ of $4 \mathrm{M} \mathrm{HCl}$ in dioxane was added, and the solution was stirred overnight at RT. Then, the solvent was removed under reduced pressure and the residue was purified by reversed-phase (RP)-HPLC (method P1) to yield cryptophycin-55 glycinate trifluoroacetate salt $(63.4 \mathrm{mg}, 82 \%$ yield) as a white powder after freeze-drying. ${ }^{1} \mathrm{H}$ NMR $(600$ $\left.\mathrm{MHz}, \mathrm{CDCl}_{3}\right): \delta(\mathrm{ppm})=0.94\left(\mathrm{~d}, J=6.5 \mathrm{~Hz}, 3 \mathrm{H}, \mathrm{uD}-\mathrm{C}^{\delta} \mathrm{H}_{3}\right)$, $0.99\left(\mathrm{~d}, J=6.5 \mathrm{~Hz}, 3 \mathrm{H}, \mathrm{uD}-\mathrm{C}^{\delta} \mathrm{H}_{3}\right), 1.00(\mathrm{~d}, J=7.2 \mathrm{~Hz}, 3 \mathrm{H}$, uA-C $\left.{ }^{\varepsilon} \mathrm{HCH}_{3}\right), 1.08$ (s, 3H, uC-C $\left.\left(\mathrm{CH}_{3}\right)_{2}\right), 1.18$ (s, 3H, uC$\left.\mathrm{C}\left(\mathrm{CH}_{3}\right)_{2}\right), 1.63-1.68\left(\mathrm{~m}, 1 \mathrm{H}, \mathrm{uD}-\mathrm{C}^{\beta} \mathrm{H}^{\mathrm{A}}\right), 1.73-1.79(\mathrm{~m}, 1 \mathrm{H}$, $\left.\mathrm{uD}-\mathrm{C}^{\gamma} \mathrm{H}\right), 1.90-1.95\left(\mathrm{~m}, 1 \mathrm{H}, \mathrm{uD}-\mathrm{C}^{\beta} \mathrm{H}^{\mathrm{B}}\right), 2.17-2.23(\mathrm{~m}, 1 \mathrm{H}$, $\left.\mathrm{uA}-\mathrm{C}^{\gamma} \mathrm{H}^{\mathrm{A}}\right), 2.54-2.57\left(\mathrm{~m}, 1 \mathrm{H}, \mathrm{uA}-\mathrm{C}^{\gamma} \mathrm{H}^{\mathrm{B}}\right), 2.64-2.69(\mathrm{~m}, 1 \mathrm{H}$, uA- $\left.{ }^{\varepsilon} \mathrm{H}\right), 2.94\left(\mathrm{dd}, J=14.5,8.5 \mathrm{~Hz}, 1 \mathrm{H}, \mathrm{uB}-\mathrm{C}^{\beta} \mathrm{H}^{\mathrm{A}}\right), 3.07-3.14$ $\left(\mathrm{m}, 3 \mathrm{H}, \mathrm{Gly}-\mathrm{H}^{\mathrm{A}}, \mathrm{uB}-\mathrm{C}^{\beta} \mathrm{H}^{\mathrm{B}}, \mathrm{uC}-\mathrm{C}^{\beta} \mathrm{H}^{\mathrm{A}}\right), 3.34-3.41(\mathrm{~m}, \mathrm{uC}-$ $\mathrm{C}^{\beta} \mathrm{H}^{\mathrm{B}}$ ), $3.67\left(\mathrm{~d}, J=16.6 \mathrm{~Hz}, 1 \mathrm{H}, \mathrm{Gly}-\mathrm{H}^{\mathrm{B}}\right), 3.88$ (s, $3 \mathrm{H}, \mathrm{uB}-$ $\left.\mathrm{OCH}_{3}\right), 4.56\left(\mathrm{td}, J=7.8,5.1 \mathrm{~Hz}, \mathrm{uB}-\mathrm{C}^{\alpha} \mathrm{H}\right), 4.73(\mathrm{t}, J=10.6$ $\left.\mathrm{Hz}, 1 \mathrm{H}, \mathrm{uA}-\mathrm{C}^{\delta} \mathrm{H}\right), 4.81\left(\mathrm{~d}, J=10.2 \mathrm{~Hz}, 1 \mathrm{H}, \mathrm{uA}-\mathrm{C}^{\eta} \mathrm{H}\right), 4.93$ (dd, $\left.J=10.9,2.7 \mathrm{~Hz}, 1 \mathrm{H}, \mathrm{uD}-\mathrm{C}^{\alpha} \mathrm{H}\right), 5.42(\mathrm{~d}, J=10.2 \mathrm{~Hz}, 1 \mathrm{H}$, uA-C $\left.{ }^{\zeta} \mathrm{H}\right), 5.74\left(\mathrm{dd}, J=15.4,1.8 \mathrm{~Hz}, 1 \mathrm{H}, \mathrm{uA}-\mathrm{C}^{\alpha} \mathrm{H}\right), 6.27(\mathrm{br}$, $1 \mathrm{H}, \mathrm{uB}-\mathrm{NH}), 6.52$ (ddd, $J=15.2,11.0,4.2 \mathrm{~Hz}, 1 \mathrm{H}, \mathrm{uA}-\mathrm{C}^{\beta} \mathrm{H}$ ), 


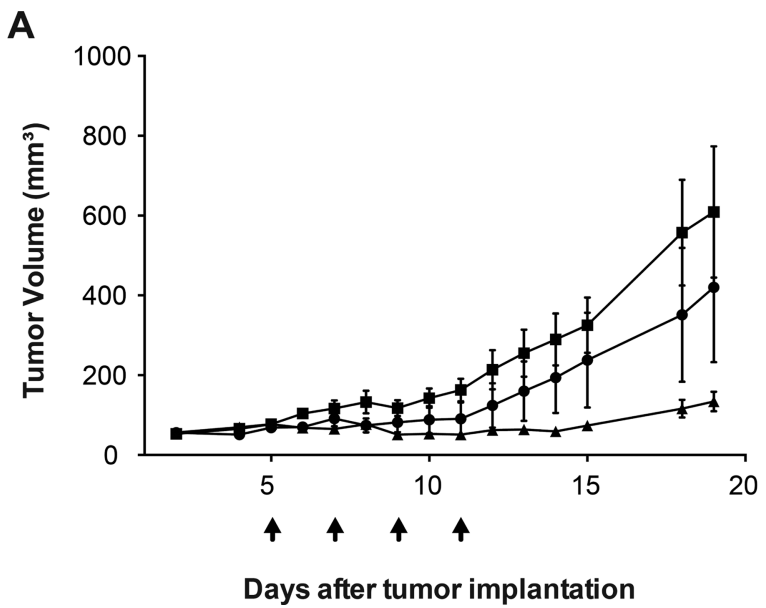

B

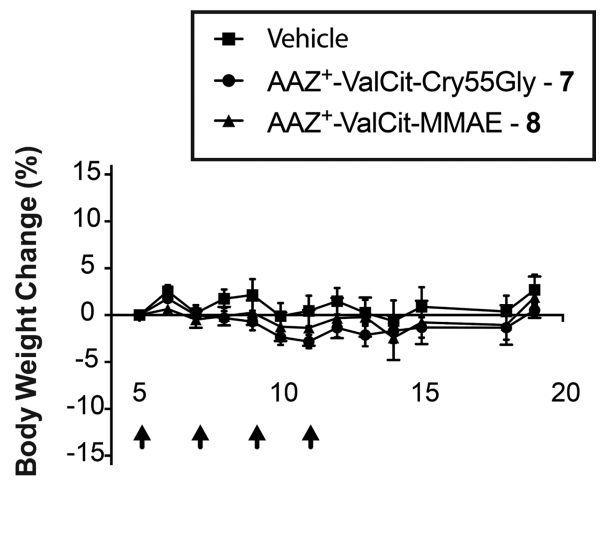

Days after tumor implantation

Figure 4. Therapy experiment of conjugates 7 and $8(250 \mathrm{nmol} / \mathrm{kg})$. (A) Tumor volume changes for different treatment groups. (B) Animal body weight changes during the in vivo efficacy study. Intravenous administration of the corresponding compound is indicated by the arrows.

$6.86\left(\mathrm{~d}, J=8.4 \mathrm{~Hz}, 1 \mathrm{H}, \mathrm{uB}-\mathrm{C}^{5 \prime} \mathrm{H}\right), 7.05(\mathrm{dd}, J=8.4,2.2 \mathrm{~Hz}$, $\left.1 \mathrm{H}, \mathrm{uB}-\mathrm{C}^{6 \prime} \mathrm{H}\right), 7.19$ (d, $\left.J=2.2 \mathrm{~Hz}, 1 \mathrm{H}, \mathrm{uB}-\mathrm{C}^{2 \prime} \mathrm{H}\right), 7.27-7.37$ (m, 5H, uA- $\left.\mathrm{C}^{\mathrm{ar}} \mathrm{H}\right)$.

4.2.2. Maleimide- $P E G_{4}-$ Val-Cit-PAB-PNP (4). Fmoc-Val-Cit$\mathrm{PABOH}(500 \mathrm{mg}, 0.83 \mathrm{mmol}$ ) was dissolved in $N$-methyl pyrrolidone $(10 \mathrm{~mL})$, diethylamine $(2 \mathrm{~mL})$ was added, and the solution was stirred overnight at room temperature. Then, the solvent was removed under high vacuum and the obtained oil was resuspended in DCM. The suspension was placed in an ultrasonic bath for $10 \mathrm{~min}$; the solid was filtered off, washed with DCM, and dried in high vacuum to yield H-Val-Cit$\mathrm{PABOH}$ as a beige solid (260 $\mathrm{mg}, 82 \%$ yield).

Maleimide- $\mathrm{PEG}_{4}-\mathrm{OH}$ (190 mg, $0.55 \mathrm{mmol}, 1.2$ equiv) and DIPEA (321 $\mu \mathrm{L}, 1.85 \mathrm{mmol}, 4$ equiv) were premixed in DMF $(6.5 \mathrm{~mL})$ and added to H-Val-Cit-PAB (175 mg, $0.46 \mathrm{mmol}, 1$ equiv). HATU (209 mg, $0.55 \mathrm{mmol}, 1.2$ equiv) and HOAt (75 $\mathrm{mg}, 0.55 \mathrm{mmol}, 1.2$ equiv) were dissolved in DMF $(6.5 \mathrm{~mL})$ and added to the reaction mixture. The solution was stirred at room temperature for $2 \mathrm{~h}$, and then, the solvent was removed under reduced pressure. The product was taken up in $\mathrm{MeOH}$, the solution filtered off, and the filtrate purified by column chromatography using $\mathrm{DCM} / \mathrm{MeOH}(8: 2)$ as an eluent to provide Maleimide- $\mathrm{PEG}_{4}$-Val-Cit-PABOH as a yellow oil (215 $\mathrm{mg}, 66 \%$ yield).

Maleimide- PEG $_{4}$-Val-Cit-PABOH $(120 \mathrm{mg}, 0.17 \mathrm{mmol}, 1$ equiv) was dissolved in anhydrous DMF $(1.5 \mathrm{~mL})$, and bis(4nitrophenyl) carbonate (103 $\mathrm{mg}, 0.34 \mathrm{mmol}, 2$ equiv) and DIPEA ( $45 \mu \mathrm{L}, 0.26 \mathrm{mmol}, 1.5$ equiv) were added. The solution was stirred at room temperature for $3 \mathrm{~h}$, and then, the solvents were removed under reduced pressure. The product was purified by column chromatography using DCM/MeOH (9:1) as an eluent to obtain 2 as a slightly yellowish solid (95 $\mathrm{mg}, 64 \%$ yield). LC-MS (method A): $t_{\mathrm{r}}=8.61 \mathrm{~min}, 92 \%$ purity $(\lambda=220 \mathrm{~nm}) . \mathrm{m} / z$ calcd for $\left[\mathrm{C}_{40} \mathrm{H}_{54} \mathrm{~N}_{7} \mathrm{O}_{15}\right]^{+}: 872.37$ $[\mathrm{M}+\mathrm{H}]^{+}$; found: 872.36 .

4.2.3. Maleimide-PEG ${ }_{4}$-Val-Cit-PABC-Cry55-gly (5). 3 (8.7 mg, $9.94 \mu \mathrm{mol}, 1$ equiv) and 4 (9.5 mg, $10.90 \mu \mathrm{mol}, 1.1$ equiv) were dissolved in DMF $(0.5 \mathrm{~mL})$, DIPEA $(5.2 \mu \mathrm{L}, 29.82 \mu \mathrm{mol}$, 3 equiv) was added, and the solution was stirred at room temperature for $3 \mathrm{~h}$. Then, it was directly purified by RPHPLC (method P1); fractions containing the desired product were freeze-dried to afford 5 as a white powder $(10.9 \mathrm{mg}, 73 \%$ yield). LC-MS (method A): $t_{\mathrm{r}}=10.52 \mathrm{~min},>99 \%$ purity $(\lambda=$
$220 \mathrm{~nm}), m / z$ calcd for $\left[\mathrm{C}_{72} \mathrm{H}_{99} \mathrm{Cl}_{2} \mathrm{~N}_{9} \mathrm{O}_{21}\right]^{2+}: 747.82[\mathrm{M}$ $+2 \mathrm{H}]^{2+}$; found: 747.82 .

4.2.4. $A A Z^{+}$(6). Compound 6 was synthesized as previously reported. $^{7}$

4.2.5. $A A Z^{+}$-ValCit-Cry55gly (7). Compound 6 (3.6 mg, $2.51 \mu \mathrm{mol}, 2.5$ equiv) was dissolved in $500 \mu \mathrm{L}$ of degassed TBS ( $\mathrm{pH} 7.4$ ). Compound 5 ( $1.5 \mathrm{mg}, 1.00 \mu \mathrm{mol}, 1.0$ equiv) was added as a DMF solution $(500 \mu \mathrm{L})$, and the reaction mixture was stirred at room temperature overnight. The crude mixture was diluted in $500 \mu \mathrm{L}$ of $\mathrm{H}_{2} \mathrm{O}$ and $500 \mu \mathrm{L}$ of $\mathrm{CH}_{3} \mathrm{CN}$, and purified by RP-HPLC (method P2). Product-containing fractions were identified by high-resolution mass spectrometry and lyophilized overnight to afford 7 ( $\mathrm{AAZ}^{+}$-ValCit-Cry55gly; $1.4 \mathrm{mg}$, $48 \%$ yield). LC-MS (method B): $t_{\mathrm{r}}=3.51 \mathrm{~min},>99 \%$ purity $(\lambda=260 \mathrm{~nm}), m / z$ calcd for $\left[\mathrm{C}_{128} \mathrm{H}_{174} \mathrm{Cl}_{2} \mathrm{~N}_{26} \mathrm{O}_{43} \mathrm{~S}_{3}\right]^{2+}$ : 1464.5378 $[\mathrm{M}+2 \mathrm{H}]^{2+}$; found: $1464.5367 ; \mathrm{m} / z$ calcd for $\left[\mathrm{C}_{128} \mathrm{H}_{175} \mathrm{Cl}_{2} \mathrm{~N}_{26} \mathrm{O}_{43} \mathrm{~S}_{3}\right]^{3+}$ : $976.6943[\mathrm{M}+3 \mathrm{H}]^{3+}$; found: 976.6956

4.3. Surface Plasmon Resonance. Surface plasmon resonance (SPR) experiments were performed at room temperature using a Biacore S200 instrument (GE Healthcare). CM5 chips (Series S) and filtered phosphate-buffered saline (PBS) pH 7.4 with dimethyl sulfoxide (DMSO) (5\% v/ v) as a flow buffer were used for all experiments. Human CAIX was immobilized on the chip to 500 response units (R.U.) using $\mathrm{EDC} \cdot \mathrm{HCl}$ and $\mathrm{NHS}$ according to the manufacturer's instructions. Serial dilutions of compound 7 ( $\mathrm{AAZ}^{+}-\mathrm{ValCit}-$ Cry55gly) in a running buffer at a flow rate of $20 \mu \mathrm{L} /$ min were used as analytes. The chip surface was regenerated after each cycle by a short treatment with DMSO (50\% v/v) in PBS. Sensorgrams were solvent-corrected and the binding kinetics was analyzed with the Biacore S200 evaluation software using the 1:1 Langmuir binding model.

4.4. Cell Culture and In Vitro Cytotoxicity Assay. The human renal cell carcinoma cell line SKRC-52 was kindly provided by Professor E. Oosterwijk (Radboud University Nijmegen Medical Centre, Nijmegen, The Netherlands). Upon thawing, cells were maintained in culture-full growth medium (Roswell Park Memorial Institute (RPMI) added with 10\% fetal calf serum (FCS) and $1 \%$ antibiotic-antimycotic; Invitrogen) at $37{ }^{\circ} \mathrm{C}$ and $5 \% \mathrm{CO}_{2}$. When reaching 90\% confluence, cells were detached using trypsin-ethylenediaminetetraacetic acid (EDTA) $0.05 \%$ (Invitrogen) and re-seeded at a dilution of 1:6. 
SKRC-52 cells were seeded in 96-well plates in RPMI added with $10 \%$ FCS $(100 \mu \mathrm{L})$ at a density of $5 \times 10^{3}$ cells/well. The medium was replaced after $24 \mathrm{~h}$ with fresh medium containing different concentrations of test substance (starting concentration of $100 \mathrm{nM}, 1: 2$ dilution steps), and plates were incubated under standard culture conditions. After $72 \mathrm{~h}$, the medium was removed, MTS cell viability dye $(20 \mu \mathrm{L}$, Promega) was added in $150 \mu \mathrm{L}$ of fresh medium, the plates were incubated for $2 \mathrm{~h}$ under standard culture conditions, and the absorbance at $490 \mathrm{~nm}$ was measured on a Spectra Max Paradigm multimode plate reader (Molecular Devices; background correction was performed by measuring the absorbance at $630 \mathrm{~nm}$ ). Experiments were performed in triplicates, and the average cell viability was calculated as measured backgroundcorrected absorbance divided by the absorbance of untreated control wells. $\mathrm{IC}_{50}$ values were determined by fitting data to the four-parameter logistic equation, using Prism 7 software (GraphPad Software) for data analysis.

4.5. Animal Studies. The animal studies were performed in accordance with Swiss animal welfare laws and regulations (license number 27/2015, granted by Veterinäramt des Kantons Zürich).

4.5.1. Tumor Implantation. SKRC-52 cells were grown as described above to $80 \%$ confluence and detached with trypsin-EDTA $0.05 \%$ (Life Technologies). Cells were rinsed once with Hank's balanced salt solution (HBSS, pH 7.4), and counted and suspended again in HBSS to give a final concentration of $3.4 \times 10^{7}$ cells $/ \mathrm{mL}$. Aliquots of $5 \times 10^{6}$ cells ( $150 \mu \mathrm{L}$ of the suspension) were injected subcutaneously into the right flank of athymic BALB/c nu/nu mice $(8-10$ weeks old females, Janvier).

4.5.2. Dose Escalation. Athymic BALB/c nu/nu mice (females, 8-10 weeks old, no tumors, Janvier) were injected intravenously with different doses of compound $7\left(\mathrm{AAZ}^{+}\right.$ValCit-Cry55gly; 10, 25, 125, 250, and $500 \mathrm{nmol} / \mathrm{kg} ; n=1$ per group) five times, once every two days (starting from day 1 ; Figure S5). None of the doses tested resulted in a significant acute body weight loss.

4.5.3. Therapy Experiment. Tumors were allowed to grow to an average volume of $75 \mathrm{~mm}^{3}$. Three groups (5 mice each) were formed randomly. The treatment was started by intravenously injecting a solution of $\mathrm{AAZ}^{+}-\mathrm{ValCit}-\mathrm{Cry} 55 \mathrm{gly}$ (compound 7), $\mathrm{AAZ}^{+}-\mathrm{ValCit}-\mathrm{MMAE}$ (compound 8), or vehicle (PBS containing $1 \%$ of DMSO) (lateral tail vein) at $250 \mathrm{nmol} / \mathrm{kg}$. All compounds were prepared and injected as solutions in sterile PBS containing 1\% DMSO. The mice were weighed, and the tumor sizes were monitored daily with an electronic caliper. Tumor volume calculation was done by multiplying (long side $) \times($ short side $) \times($ short side $) \times 0.5$. Once the termination criteria were reached, the animals were sacrificed. GraphPad Prism 7 was used for data analysis (regular two-way ANOVA followed by Bonferroni test).

\section{ASSOCIATED CONTENT}

\section{S Supporting Information}

The Supporting Information is available free of charge on the ACS Publications website at DOI: 10.1021/acsomega.8b02350.

Materials and methods, characterization of new compounds, and dose-escalation graph (PDF)

\section{AUTHOR INFORMATION}

\section{Corresponding Authors}

*E-mail: neri@pharma.ethz.ch (D.N.).

*E-mail: norbert.sewald@uni-bielefeld.de (N.S.).

ORCID $\odot$

Samuele Cazzamalli: 0000-0003-0510-5664

Norbert Sewald: 0000-0002-0309-2655

\section{Author Contributions}

${ }^{\perp}$ S.C. and E.F. contributed equally to this work.

\section{Notes}

The authors declare the following competing financial interest(s): D.N. is a co-founder and shareholder of Philogen (www.philogen.com), a Swiss-Italian Biotech company that operates in the field of ligand-based pharmacodelivery.

\section{ACKNOWLEDGMENTS}

This project has received funding from the European Union's Horizon 2020 research and innovation programme under the Marie Skłodowska-Curie grant agreement No 642004 (ETN MAGICBULLET). The authors gratefully acknowledge financial support from ETH Zürich, the Swiss National Science Foundation (Project Nos. 310030B 163479/1 and SINERGIA CRSII2_160699/1), ERC Advanced Grant "Zauberkugel” (670603), and Kommission für Technologie und Innovation (Grant No. 17072.1). The authors acknowledge M. Wißbrock, A. Nieß, and C. Michalek for technical support.

\section{REFERENCES}

(1) van der Veldt, A. A. M.; Hendrikse, N. H.; Smit, E. F.; Mooijer, M. P. J.; Rijnders, A. Y.; Gerritsen, W. R.; Van Der Hoeven, J. J. M.; Windhorst, A. D.; Lammertsma, A. A.; Lubberink, M. Biodistribution and Radiation Dosimetry of ${ }^{11} \mathrm{C}$-Labelled Docetaxel in Cancer Patients. Eur. J. Nucl. Med. Mol. Imaging 2010, 37, 1950-1958.

(2) van der Veldt, A. A. M.; Lubberink, M.; Mathijssen, R. H. J.; Loos, W. J.; Herder, G. J. M.; Greuter, H. N.; Comans, E. F. I.; Rutten, H. B.; Eriksson, J.; Windhorst, A. D.; et al. Toward Prediction of Efficacy of Chemotherapy: A Proof of Concept Study in Lung Cancer Patients Using $\left[{ }^{11} \mathrm{C}\right]$ Docetaxel and Positron Emission Tomography. Clin. Cancer Res. 2013, 19, 4163-4173.

(3) Krall, N.; Pretto, F.; Decurtins, W.; Bernardes, G. J. L.; Supuran, C. T.; Neri, D. A Small-Molecule Drug Conjugate for the Treatment of Carbonic Anhydrase IX Expressing Tumors. Angew. Chem., Int. Ed. 2014, 53, 4231-4235.

(4) Srinivasarao, M.; Low, P. S. Ligand-Targeted Drug Delivery. Chem. Rev. 2017, 117, 12133-12164.

(5) Carter, P. J.; Lazar, G. A. Next Generation Antibody Drugs: Pursuit of the "High-Hanging Fruit". Nat. Rev. Drug Discovery 2018, 17, 197-223.

(6) Beck, A.; Goetsch, L.; Dumontet, C.; Corvaïa, N. Strategies and Challenges for the next Generation of Antibody-drug Conjugates. Nat. Rev. Drug Discovery 2017, 16, 315-337.

(7) Cazzamalli, S.; Dal Corso, A.; Widmayer, F.; Neri, D. Chemically Defined Antibody- and Small Molecule-Drug Conjugates for in Vivo Tumor Targeting Applications: A Comparative Analysis. J. Am. Chem. Soc. 2018, 140, 1617-1621.

(8) Yuan, F.; Dellian, M.; Fukumura, D.; Leunig, M.; Berk, D. A.; Torchilin, V. P.; Jain, R. K. Vascular Permeability in a Human Tumor Xenograft: Molecular Size Dependence and Cutoff Size. Cancer Res. 1995, 55, 3752-3756.

(9) Firer, M. A.; Gellerman, G. Targeted Drug Delivery for Cancer Therapy: The Other Side of Antibodies. J. Hematol. Oncol. 2012, 5, 70.

(10) Jefferis, R. Posttranslational Modifications and the Immunogenicity of Biotherapeutics. J. Immunol. Res. 2016, No. 5358272. 
(11) Leamon, C. P.; Parker, M. A.; Vlahov, I. R.; Xu, L.-C.; Reddy, J. A.; Vetzel, M.; Douglas, N. Synthesis and Biological Evaluation of EC20: A New Folate-Derived, 99m Tc-Based Radiopharmaceutical. Bioconjugate Chem. 2002, 13, 1200-1210.

(12) Hillier, S. M.; Maresca, K. P.; Lu, G.; Merkin, R. D.; Marquis, J. C.; Zimmerman, C. N.; Eckelman, W. C.; Joyal, J. L.; Babich, J. W. ${ }^{99 \mathrm{~m}}$ Tc-Labeled Small-Molecule Inhibitors of Prostate-Specific Membrane Antigen for Molecular Imaging of Prostate Cancer. J. Nucl. Med. 2013, 54, 1369-1376.

(13) Ginj, M.; Zhang, H.; Waser, B.; Cescato, R.; Wild, D.; Wang, X.; Erchegyi, J.; Rivier, J.; Mäcke, H. R.; Reubi, J. C. Radiolabeled Somatostatin Receptor Antagonists Are Preferable to Agonists for in Vivo Peptide Receptor Targeting of Tumors. Proc. Natl. Acad. Sci. U.S.A. 2006, 103, 16436-16441.

(14) Cazzamalli, S.; Ziffels, B.; Widmayer, F.; Murer, P.; Pellegrini, G.; Pretto, F.; Wulhfard, S.; Neri, D. Enhanced Therapeutic Activity of Non-Internalizing Small Molecule-Drug Conjugates Targeting Carbonic Anhydrase IX in Combination With Targeted Interleukin-2. Clin. Cancer Res. 2018, 24, 3656-3667.

(15) Wichert, M.; Krall, N. Targeting Carbonic Anhydrase IX with Small Organic Ligands. Curr. Opin. Chem. Biol. 2015, 26, 48-54.

(16) Supuran, C. T.; Alterio, V.; Fiore, A. Di; D’Ambrosio, K.; Carta, F.; Monti, S. M.; De Simone, G. Inhibition of Carbonic Anhydrase IX Targets Primary Tumors, Metastases, and Cancer Stem Cells: Three for the Price of One. Med. Res. Rev. 2018, 1799.

(17) Krall, N.; Pretto, F.; Neri, D. A Bivalent Small Molecule-Drug Conjugate Directed against Carbonic Anhydrase IX Can Elicit Complete Tumour Regression in Mice. Chem. Sci. 2014, 5, 36403644.

(18) Perrino, E.; Steiner, M.; Krall, N.; Bernardes, G. J. L.; Pretto, F.; Casi, G.; Neri, D. Curative Properties of Noninternalizing AntibodyDrug Conjugates Based on Maytansinoids. Cancer Res. 2014, 74, 2569-2578.

(19) Dorywalska, M.; Dushin, R.; Moine, L.; Farias, S. E.; Zhou, D.; Navaratnam, T.; Lui, V.; Hasa-Moreno, A.; Casas, M. G.; Tran, T.-T.; et al. Molecular Basis of Valine-Citrulline-PABC Linker Instability in Site-Specific ADCs and Its Mitigation by Linker Design. Mol. Cancer Ther. 2016, 15, 958-970.

(20) Dal Corso, A.; Cazzamalli, S.; Gébleux, R.; Mattarella, M.; Neri, D. Protease-Cleavable Linkers Modulate the Anticancer Activity of Noninternalizing Antibody - Drug Conjugates. Bioconjugate Chem. 2017, 28, 1826-1833.

(21) Dal Corso, A.; Gébleux, R.; Murer, P.; Soltermann, A.; Neri, D. A Non-Internalizing Antibody-Drug Conjugate Based on an Anthracycline Payload Displays Potent Therapeutic Activity in Vivo. J. Controlled Release 2017, 264, 211-218.

(22) Marks, I. S.; Gardeen, S. S.; Kurdziel, S. J.; Nicolaou, S. T.; Woods, J. E.; Kularatne, S. A.; Low, P. S. Development of a Small Molecule Tubulysin B Conjugate for Treatment of Carbonic Anhydrase IX Receptor Expressing Cancers. Mol. Pharm. 2018, 15, 2289-2296.

(23) Wichert, M.; Krall, N.; Decurtins, W.; Franzini, R. M.; Pretto, F.; Schneider, P.; Neri, D.; Scheuermann, J. Dual-Display of Small Molecules Enables the Discovery of Ligand Pairs and Facilitates Affinity Maturation. Nat. Chem. 2015, 7, 241-249.

(24) Cazzamalli, S.; Dal Corso, A.; Neri, D. Acetazolamide Serves as Selective Delivery Vehicle for Dipeptide-Linked Drugs to Renal Cell Carcinoma. Mol. Cancer Ther. 2016, 15, 2926-2936.

(25) Cazzamalli, S.; Dal Corso, A.; Neri, D. Linker Stability Influences the Anti-Tumor Activity of Acetazolamide-Drug Conjugates for the Therapy of Renal Cell Carcinoma. J. Controlled Release 2017, 246, 39-45.

(26) Weiss, C.; Figueras, E.; Borbely, A. N.; Sewald, N. Cryptophycins: Cytotoxic Cyclodepsipeptides with Potential for Tumor Targeting. J. Pept. Sci. 2017, 23, 514-531.

(27) Schwartz, R. E.; Hirsch, C. F.; Sesin, D. F.; Flor, J. E.; Chartrain, M.; Fromtling, R. E.; Harris, G. H.; Salvatore, M. J.; Liesch, J. M.; Yudin, K. Pharmaceuticals from Cultured Algae. J. Ind. Microbiol. 1990, 5, 113-124.
(28) Eißler, S.; Stoncius, A.; Nahrwold, M.; Sewald, N. The Synthesis of Cryptophycins. Synthesis 2006, 3747-3789.

(29) D’Agostino, G.; Del Campo, J.; Mellado, B.; Izquierdo, M. A.; Minarik, T.; Cirri, L.; Marini, L.; Perez-Gracia, J. L.; Scambia, G. A Multicenter Phase II Study of the Cryptophycin Analog LY355703 in Patients with Platinum-Resistant Ovarian Cancer. Int. J. Gynecol. Cancer 2006, 16, 71-76.

(30) Sammet, B.; Bogner, T.; Nahrwold, M.; Weiss, C.; Sewald, N. Approaches for the Synthesis of Functionalized Cryptophycins. J. Org. Chem. 2010, 75, 6953-6960.

(31) Nahrwold, M.; Weiß, C.; Bogner, T.; Mertink, F.; Conradi, J.; Sammet, B.; Palmisano, R.; Gracia, S. R.; Preuße, T.; Sewald, N. Conjugates of Modified Cryptophycins and RGD-Peptides Enter Target Cells by Endocytosis. J. Med. Chem. 2013, 56, 1853-1864.

(32) Weiss, C.; Sammet, B.; Sewald, N. Recent Approaches for the Synthesis of Modified Cryptophycins. Nat. Prod. Rep. 2013, 30, 924940.

(33) Figueras, E.; Borbély, A.; Ismail, M.; Frese, M.; Sewald, N. Novel Unit B Cryptophycin Analogues as Payloads for Targeted Therapy. Beilstein J. Org. Chem. 2018, 14, 1281-1286.

(34) Eißler, S.; Bogner, T.; Nahrwold, M.; Sewald, N. Efficient Synthesis of Cryptophycin-52 and Novel Para- Alkoxymethyl Unit A Analogues. Chem. - Eur. J. 2009, 15, 11273-11287.

(35) Verma, V. A.; Pillow, T. H.; Depalatis, L.; Guangmin, L.; Phillips, G. L.; Polson, A. G.; Raab, H. E.; Spencer, S.; Zheng, B. The Cryptophycins as Potent Payloads for Antibody Drug Conjugates. Bioorg. Med. Chem. Lett. 2015, 25, 864-868.

(36) Bigot, A.; Bouchard, H.; Brun, M.-P.; Clerc, F.; Zhang, J. WO2017/076998A1, 2017.

(37) Chen, H.; Lin, Z.; Arnst, K. E.; Miller, D. D.; Li, W. Tubulin Inhibitor-Based Antibody-Drug Conjugates for Cancer Therapy. Molecules 2017, 22, No. 1281.

(38) Liang, J.; Moore, R. E.; Moher, E. D.; Munroe, J. E.; Al-Awar, R. S.; Hay, D. A.; Varie, D. L.; Zhang, T. Y.; Aikins, J. A.; Martinelli, M. J.; et al. Cryptophycins-309, 249 and Other Cryptophycin Analogs: Preclinical Efficacy Studies with Mouse and Human Tumors. Invest. New Drugs 2005, 23, 213-224.

(39) Steinkühler, M. C.; Gallinari, M. P.; Osswald, B.; Sewald, N.; Ritzefeld, M.; Frese, M.; Figueras, E.; Pethö, L. WO2016/146638A1, 2016. 